\title{
Knowledge and Adoption of Improved Post Harvest Technologies of Maize by Farm Women of Agro-Climatic Zone IV A of Rajasthan, India
}

\author{
Chamandeep Kaur $^{1}$, Dhriti Solanki ${ }^{2}$ and L.R. Choudhary ${ }^{3 *}$ \\ ${ }^{1}$ College of Home Science, MPUAT, Udaipur, Rajasthan, India \\ ${ }^{2}$ HECM Department, College of Home Science, MPUAT, Udaipur, Rajasthan, India \\ ${ }^{3}$ Department of Extension Education, Rajasthan College of Agricultural, \\ Udaipur, Rajasthan 303001, India \\ *Corresponding author
}

\begin{tabular}{|c|c|}
\hline & A B S T R A C T \\
\hline $\begin{array}{l}\text { Knowledge, } \\
\text { Adoption, } \\
\text { Post harvest } \\
\text { technologies, } \\
\text { Maize }\end{array}$ & \multirow{3}{*}{$\begin{array}{l}\text { The present study was undertaken to assess and compare the knowledge of } \\
\text { improved post harvest technologies by farm women. The study was conducted } \\
\text { in two purposively selected districts viz. Udaipur and Chittorgarh of Agro } \\
\text { climatic zone IV A of Rajasthan. Two Panchayat samities from each district } \\
\text { were selected purposively and three villages from each Panchayats samiti were } \\
\text { selected on random basis. Thus, there were total six villages from each district } \\
\text { and total } 12 \text { villages from both the districts. Fifteen farmers from each village } \\
\text { and } 90 \text { farm women from each district were selected. Thus, total sample for the } \\
\text { present study was } 180 \text { respondents. The interview schedule technique was used } \\
\text { to know the knowledge of the respondent post harvest technologies and Extent } \\
\text { of adoption of post harvesting technologies by the farm women. }\end{array}$} \\
\hline Article Info & \\
\hline $\begin{array}{l}21 \text { June } 2017 \\
\text { Available Online: } \\
10 \text { July } 2017\end{array}$ & \\
\hline
\end{tabular}

\section{Introduction}

Maize is the third most important cereal crop of world. It is a principal staple food in many countries particularly in the tropics and subtropics. It is widely cultivated throughout the world. The United States produced 40 per cent of the world's harvest, other top producing countries include China, Brazil, Mexico, Indonesia, India, France and Argentina. Maize is regarded as the "Queen of Cereals". Being a $\mathrm{C}_{4}$ plant, it utilizes solar radiation more efficiently even at higher radiation intensity. In general, it has greater worldwide significance as human food, animal feed and a source of large number of industrial products. Maize is currently produced on nearly 100 million hectares in 125 developing countries and is among the three most widely grown crops in 75 of those countries (FAOSTAT, 2013). Between now and 2050, the demand for maize in the developing world will double and, by 2025 , maize is expected to become the crop with the greatest production globally and in the developing world. Apart from facing the challenge of increasing the food production in the country, the another challenge which the Indian farmers are facing is to reduce the losses of food grain which occurs at different stages of post harvest operations after harvesting till marketing of the produce. Post 
harvest handling is the stage of crop production immediately following harvest, including cooling, cleaning, sorting and packing.

The instant a crop is removed from the ground, or separated from its parent plant, it begins to deteriorate. Post harvest treatment largely determines final quality, whether a crop is sold for fresh consumption, or used as an ingredient in a processed food product.

The most important goals of post harvest handling are to keep the product cool, avoid moisture loss and slow down undesirable chemical changes and to avoid physical damage such as bruising, to delay spoilage. Sanitation is also an important factor to reduce the activities of pathogens that could be carried by fresh produce. The post harvest management and loss prevention of food grains is prime responsibility of farm women as the operations like winnowing, drying and storage of produce are predominately done by them.

Due to illiteracy and lack of scientific knowledge million tones food grains are either damaged or lost. Although intensive efforts have been made by the Government for dissemination of technologies related to post harvest however, there is conspicuous sex bias in extension and training programmes of women. The bias is so deeply rooted that in areas where women's participation is almost monopoly like winnowing, drying, storage and processing of grains etc., the men are being trained. The result is that women is totally ignored and unaware about scientific methods of post harvest and are bound to use traditional practices which are passed from generation to generation. Thus, the present study was taken to assess knowledge and adoption of improved post harvest technologies by farm women.

\section{Materials and Methods}

The present study was conducted in the Agroclimatic zone IV A i.e. Sub- humid Southern Plain and Aravali Hills of Rajasthan State. Zone IV A covers all the tehsils of Bhilwara and Rajsamand districts, all tehsils of Udaipur district except Dhariyawad, Salumber and Sarada, all tehsils of Chittorgarh district and Aburoad and Pindwara tehsils of Sirohi district.

Out of these, two districts namely Udaipur and Chittorgarh were selected purposively on the basis of highest production of maize. Zone IV-A of Rajasthan covers fourteen panchayat samities of Udaipur and eleven of Chittorgarh district. Out of these, two panchayat samities from each district were selected purposively on the basis of highest production of maize. Thus, from Udaipur district, Mavli and Girwa panchayat samities and from, Begu and Chittorgarh panchayat samities were selected. In each district, panchayat samiti wise list of villages was prepared and from the list three villages from each panchayat samiti were selected on random basis. Thus, there were six villages from each district making total 12 villages from both the districts. From Udaipur, Girva panchayat samiti Bhallon Ka Guda, Sakroda, Bichhadi and from Mavli panchayat samiti Khempur, Badgaon and Martadi. From Chittorgarh, Begu panchayat samiti Jainagar, Sonagar, Katunda and from Chittorgarh panchayat samiti Oradhi, Jalampur, Khar villages selected. Collected data were tabulated and analyzed by using mean, frequency, percentage and mean percent score.

\section{Results and Discussion}

Knowledge of the farm women about improved post harvest technologies of maize

Knowledge assessment of the farm women regarding improved post harvest technologies 
Table 1 depicts that they possessed poor knowledge about improved post harvest technologies with overall MPS 30.42. Categorization of the farm women in various knowledge categories highlights that majority of them were found in poor knowledge category in components time of harvesting and use of fumigants $(86.67 \%)$. In components, storage structures, use of rodenticides and considerations in storage of grains, 73.33 per cent farm women belonged to average knowledge category. In component storage pests, majority of the women $(73.33 \%)$ belonged to good knowledge category.

The findings of the study are in contrast with results of study by Sharma (2005) who concluded that the farm women had average knowledge of post harvest technologies of cereal crops with a overall mean percent score 51.82. Component wise knowledge of the farm women highlights that they possessed poor knowledge in components use of rodenticides (MPS 28.89), use of fumigants (MPS 17.73) and time of harvesting (MPS 13.33).The knowledge of the farm women was found to be average in components considerations in storage of grains and storage structure with MPS 40.00 and 35.56 MPS, respectively. In component storage pests, the women possessed good knowledge with MPS 73.33.The poor knowledge of the women was due to the reason that majority of them have not attended any training programmes related to post harvest technologies and hence were not aware about improved post harvest technologies of maize.

\section{Adoption of improved post harvest technologies of maize by the farm women}

The extent of adoption of improved post harvest technologies of maize by the respondents was judged under three categories as high, medium and low adoption on the basis of MPS. The results pertaining to this are presented in the section. Perusal of table 2 depicts that farm families had medium level of adoption of improved post harvest technologies of maize with overall MPS 59.44. This is further depicted by categorization of the respondents in adoption categories that majority of the respondents $(59.44 \%)$ belonged to medium adoption category.

Component wise adoption of post harvest technologies reveals that in component time of harvesting MPS was 100 which indicates that all of them harvested the crop at the right time and stage. In case of storage structures, the adoption score was 45 per cent which indicates average adoption of the practice by the respondents. It is also depicted by categorization of the respondents in adoption categories that 53.33 per cent respondents belonged to medium adoption category whereas, 33.33 and 13.33 per cent respondents were found in low and high adoption category, respectively. With regard to use of fumigants, it was found that the MPS was only 26.67 indicating low adoption of the practice by the respondents. It is also depicted by the categorization of the respondents in adoption categories that majority of them (73.33\%) belonged to low adoption category. The respondents were following the practice of use of rodenticides for rat control with overall MPS 73.33. The respondents reported that they used zinc phosphide for rat control at home as well as farm. Anticoagulants viz. rodoferon and bromilidion were not used by any of the respondents due to lack of knowledge. The findings are in contrast with the findings of Sihag and Singh (2008) who concluded least adoption of rat control measures by the respondents.

With respect to considerations in storage of grains, it was found that majority of the respondents $(57.78 \%)$ belonged to medium adoption category with MPS 63.89. In discussion with the respondents they reported that during storage of food grains they follow certain precautions like did not mix old and new grains, store grains at room temperature and keep the storage structure air tight. 
Table.1 Distribution of the farm women by their knowledge regarding improved post harvest technologies of maize

\begin{tabular}{|c|c|c|c|c|c|c|c|c|}
\hline \multirow{3}{*}{$\begin{array}{l}\text { S. } \\
\text { No. }\end{array}$} & \multirow{3}{*}{ Components } & \multicolumn{6}{|c|}{$\operatorname{Farm} W o m e n(n=180)$} & \multirow{3}{*}{$\begin{array}{l}\text { Good } \\
\text { f }\end{array}$} \\
\hline & & \multicolumn{2}{|l|}{ Good } & \multicolumn{2}{|c|}{ Average } & \multicolumn{2}{|l|}{ Poor } & \\
\hline & & $\mathbf{f}$ & $\%$ & $\mathbf{f}$ & $\mathbf{f}$ & $\%$ & f & \\
\hline$\overline{11}$ & Time of harvesting & 24 & 13.33 & 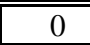 & 0.00 & 156 & 86.67 & 13.33 \\
\hline 2 & Storage structure & 0 & 0.00 & 132 & 73.33 & 48 & 26.67 & 35.56 \\
\hline 3 & Use of fumigants & 0 & 0.00 & 24 & 13.33 & 156 & 86.67 & 17.33 \\
\hline 4 & Use of rodenticides & 12 & 6.67 & 132 & 73.33 & 36 & 20.00 & 28.89 \\
\hline 5 & Storage pests & 132 & 73.33 & 0 & 0.00 & 48 & 26.67 & 73.33 \\
\hline$\overline{66}$ & Considerations in storage of grains & 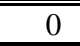 & 0.00 & 132 & 73.33 & 48 & 26.67 & 40.00 \\
\hline & Overall & 0 & 0.00 & 72 & 40.00 & 108 & 60.00 & 30.42 \\
\hline
\end{tabular}

Table 2 Distribution of the farm families by the adoption of improved post harvest technologies

\begin{tabular}{|c|c|c|c|c|c|c|c|c|}
\hline \multirow{3}{*}{ S. No. } & \multirow{3}{*}{ Components } & \multicolumn{6}{|c|}{ Adoption Categories } & \multirow{3}{*}{ MPS } \\
\hline & & \multicolumn{2}{|c|}{ High } & \multicolumn{2}{|c|}{ Medium } & \multicolumn{2}{|c|}{ Low } & \\
\hline & & $\bar{f}$ & $\%$ & $\mathbf{f}$ & $\%$ & $\overline{\mathbf{f}}$ & $\%$ & \\
\hline 1 & Time of harvesting & 180 & 100.0 & 0 & 0.00 & 0. & 0.00 & 100.0 \\
\hline 2 & Storage structure & 24 & 13.33 & 96 & 53.33 & 60 & 33.3 & 45.00 \\
\hline 3 & Use of fumigants & 48 & 26.67 & 0 & 0.00 & 132 & 73.3 & 26.67 \\
\hline 4 & Use of rodenticides & 96 & 53.33 & 72 & 40.00 & 12 & 6.67 & 73.33 \\
\hline \multirow[t]{2}{*}{$\overline{5}$} & Considerations in storage of grains & 75 & 41.67 & 104 & 57.78 & 1 & 0.56 & 63.89 \\
\hline & Overall & 72 & 40.00 & 107 & 59.44 & 1 & 0.56 & 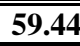 \\
\hline
\end{tabular}

In conclusion, on the basis of findings it could be concluded that the farm women had poor knowledge about improved post harvest technologies of maize however, the adoption was found to be average. This was due to the reason that efforts should be made to impart knowledge to farm women so that they can know the scientific reasons for adoption of a particular practice prior to its adoption.

\section{References}

Sihag, S. and Singh, A.R. 2008. Knowledge and adoption of post-harvest technology of cereals. Rajasthan J. Extension Edu., 16: 77-80.

FAO STAT. 2013. Food and Agriculture Organization of the United Nation retrieved from http://Fao3.fao.org/faostatgateway/go/to on October $20^{\text {th }}, 2013$.

\section{How to cite this article:}

Chamandeep Kaur, Dhriti Solanki and Choudhary, L.R. 2017. Knowledge and Adoption of Improved Post Harvest Technologies of Maize by Farm Women of Agro-climatic Zone IV A of Rajasthan. Int.J.Curr.Microbiol.App.Sci. 6(7): 2310-2313. doi: https://doi.org/10.20546/ijcmas.2017.607.272 